\title{
Tax benefits for foreign-based charities: key challenges of the non-discrimination rule of the European Court for Justice
}

\author{
Thomas von Hippel
}

Published online: 4 July 2009

(C) The Author(s) 2009. This article is published with open access at Springerlink.com

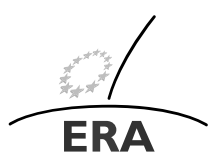

EUROPÄISCHE RECHTSAKADEMIE ACADEMY OF EUROPEAN LAW ACADEMIE DE DROIT EUROPEEN ACCADEMIA DI DIRITTO EUROPEO

TRIER - TREVES - TREVIRI

\begin{abstract}
The European Court of Justice has recently established a non-discrimination rule in the field of tax benefits, prohibiting discrimination against foreign-based charities which meet the requirements of national tax law for a residential charity. This non-discrimination approach requires challenging and complex comparability tests. It will often be difficult and expensive for charities to take advantage of the adjudication of the European Court of Justice.
\end{abstract}

Keywords Non-discrimination - Charities - Tax benefits · Cross-border donations · Persche case

\section{Introduction}

Cross-border activities by charities (public benefit organisations) have become far from uncommon. Numerous examples can be found of such activities, which may involve both grant activities as well as cross-border activities in order to obtain income by the administration of the charities' assets (e.g., income from the renting of foreign real estates, fundraising activities abroad (e.g., via alumni) or trading abroad.

Almost all member states have tax benefits for charities-which seem to be surprisingly similar in structure, although there may be some differences in their detail.

This article is a written version of the presentation given by the author at the ERA briefing "The Persche case-removing the barriers to cross-border charitable giving?" held in Brussels on 10 March, 2009.

T. von Hippel $(\varangle)$

Max-Planck-Institute for Comparative and International Law, Mittelweg 187, 20148 Hamburg, Germany

e-mail: hippel@mpipriv-hh.mpg.de 
As regards cross-border activities and the barriers created to these by the national tax laws of member states, two constellations of cross-border transactions ought to be distinguished:

- The outbound constellation concerns the treatment of a foundation by its state of residence which might hinder the foundation from collecting, investing, or spending its money in another area.

- In the inbound constellation, a member state restricts or discriminates against certain activities of non-resident foundations within its territory.

As a rule, none of the member states have barriers to outbound constellations. Thus a charity generally is entitled by its state of residence to collect, invest, or spend its money elsewhere without losing its tax benefits.

In the inbound constellation, however, almost all member states have traditionally had discriminatory rules which provide that non-resident charities be denied all or some tax benefits which domestic legislators have grant to resident charities. ${ }^{1}$ Such rules or equivalent administrative practice seem to exist in most member states (viz., Austria, Belgium, Cyprus, the Czech Republic, Denmark, Estonia, Finland, Germany, Greece, Hungary, Italy, Latvia, Luxembourg, Malta, Portugal, Romania, Slovakia, Slovenia, Sweden, and the United Kingdom). Other countries are less strict but still maintain different sets of rules for resident and non-resident foundations. Spain, for example, has an explicit provision in its domestic law according to which a local representative office of a non-resident charity is placed on equal footing with a resident charity. Similar rules can be found in Bulgaria, Ireland, Lithuania, and Poland. In France a foreign charity will be entitled to receive similar tax privileges if it performs its activities on French territory and is regarded as having a charitable purpose (public benefit purpose) in France.

In either case, such rules constitute inbound discriminations. This is particularly true where they create higher tax burdens for incoming non-resident charities, as compared to resident charities in a ceteris paribus situation.

\section{A look back: the establishment of a non-discrimination rule by the European Court of Justice}

European law as interpreted by the European Court of Justice is gaining more and more influence on the member states' national laws. One main objective of the decisions of the European Court of Justice concerning business and other associations is to identify barriers and restrictions resulting from national legal rules and principles that make the exercise of the fundamental freedoms guaranteed by the EC Treatyespecially the freedom of establishment-less attractive.

It has by now become clear, that the impact of the fundamental freedoms is also relevant in the field of taxation law-because such barriers can also exist in the field of tax law. Nevertheless, until the turn of the millennium almost nobody realised that in the field of tax benefits for charities, the fundamental freedoms of the EC

\footnotetext{
${ }^{1}$ On this constellation, see von Hippel/Walz [4], p. 112.
} 
Treaty may be relevant. ${ }^{2}$ However, when it become apparent that national tax laws concerning inheritance may not discriminate against foreign heirs or foreign investment because of the fundamental rule of free movement of capital, the problem was discovered also to exist in the field of tax benefits for charities.

Two cases in particular involve a discussion of the impact of the fundamental freedoms to inbound tax law barriers, the Stauffer decision and the Persche decision.

\subsection{Stauffer: discrimination of a real estate investment of a foreign-based charity}

As far as the tax treatment of non-resident charities is concerned, the European Court of Justice has made the first and most significant step by its decision of 14 September 2006 in the Centro Musicologia di Walter Stauffer case. ${ }^{3}$

This inbound case concerned an Italy-based public benefit foundation (the Stauffer Foundation) which made a real property investment in Germany. While income from such investments is usually tax-exempt if derived by a public benefit institution resident in Germany, the clear wording of Germany's Corporate Income Tax Act makes clear that the exemption is not available for non-resident institutions like the Stauffer Foundation.

The case raises several intricate questions regarding the fundamental freedoms, some of which were answered by the European Court of Justice in its preliminary ruling:

- Are the fundamental freedoms applicable to real estate investments of a for-profit institution as well as to a non-profit institution? (If so, which fundamental freedoms in particular?)

- Is there any justification for the instant restriction?

- If there is no justification: when is a foreign public benefit foundation comparable to a national one so that a restriction implies unjustified discrimination?

\subsubsection{Applicability of fundamental freedoms to foreign investments of charities}

In Stauffer the European Court of Justice determined that the fundamental EC Treaty freedoms were applicable. In the specific case, the freedom of establishment was held not to be involved, because the Italian foundation had not secured a permanent presence in Germany. (The services ancillary to the letting of the property were provided by a German property management agent. $)^{4}$ However, according to the Court of Justice, the free movement of capital was applicable, because 'investments in real estate' were included in the nomenclature of the (former) Council Directive 88/361/EEC of 24 June 1988, and because it is settled case-law of the Court that the content of nomenclature can be used in order to define "capital movements". 5

\footnotetext{
${ }^{2}$ See e.g., the German Federal Tax Court (Bundesfinanzhof-BFH), BStB1. III 1967, 116, rejecting tax benefits in case of a cross-border donation, because of the clear wording of the German tax law. The question whether the German tax law infringed the fundamental freedoms of the EC Treaty was not raised.

${ }^{3}$ Case C-386/04 Centro di Musicologia Walter Stauffer v. Finanzamt München für Körperschaften [2006] ECR I-8203.

${ }^{4}$ Case C-386/04, [2006] ECR I-8203, paragraphs 19-20.

${ }^{5}$ Case C-386/04, [2006] ECR I-8203, paragraph 22.
} 


\subsubsection{No Justification}

The Court of Justice clarified that restrictions of the fundamental freedoms cannot be justified in the field of the taxation of charities more easily than elsewhere. The Court denied in particular any justification for the total exclusion of any foreign public benefit foundation whether (1) because of the special provisions of Art. 87(3)(d) and Art. 151 of the EC Treaty, ${ }^{6}(2)$ because of the need of effective fiscal supervision (which only allows "measures enabling it to [be ascertained] in a clear and precise manner whether the foundation meets the conditions imposed by national law"), ${ }^{7}$ (3) because of the need to ensure the cohesion of the national tax system, ${ }^{8}$ or (4) because of the need to protect the basis of tax revenue and to the fight crime. ${ }^{9}$

\subsubsection{Comparability of a foreign charity with a national charity}

The European Court of Justice was not competent to decide whether the Italian foundation in this specific case was comparable to a tax-exempt German foundation, because the interpretation of national (tax) law is a task for the national courts.

However, the European Court of Justice provided hints concerning the appropriate criteria for the comparability test: According to the European Court of Justice, the Italian foundation had to meet all the requirements of German tax law, except residence in Germany. ${ }^{10}$ For this test, it was not sufficient that the Italian foundation had the status of a tax-exempt foundation according to Italian tax law. ${ }^{11}$

\subsection{Persche: discrimination regarding direct cross-border donations}

In Persche the European Court of Justice had to decide whether the fundamental freedoms of the EC Treaty also preclude discrimination in the case of a donation to a foreign-based foundation. ${ }^{12}$

A German-resident individual Hein Persche donated towels, walking frames and other medical devices to a social institution in Portugal in 2003. The taxation authorities in Germany refused any deduction for tax purposes of donations on the grounds that the recipient institution was not resident in Germany. Germany's Federal Tax Court left open the question whether requirements other than the recipient's residence were met. The Court made clear, however, that at least for the purpose of its own rulings, the compatibility of the residence criterion was decisive.

In this case, it the European Court of Justice had to answer the following legal questions:

\footnotetext{
${ }^{6}$ Case C-386/04, [2006] ECR I-8203, paragraph 45.

${ }^{7}$ Case C-386/04, [2006] ECR I-8203, paragraphs 47-50, especially paragraph 48.

${ }^{8}$ Case C-386/04, [2006] ECR I-8203, paragraphs 52-59.

${ }^{9}$ Case C-386/04, [2006] ECR I-8203, paragraphs 60-61.

${ }^{10}$ Case C-386/04, [2006] ECR I-8203, paragraph 40.

${ }^{11}$ Case C-386/04, [2006] ECR I-8203, paragraph 39; see also the Opinion of the Advocate General StixHackl in Case C-386/04, paragraph 94.

${ }^{12}$ Case C-318/07 Hein Persche/Finanzamt Lüdenscheid, judgment from 27 January 2009, not yet reported.
} 
- Are the fundamental freedoms also applicable to donations to a foreign charity?

- If the fundamental freedoms are applicable, was there any justification for the instant restriction?

- If there was no justification, is a foreign charity comparable to a national one, so that a restriction involved unjustified discrimination?

\subsubsection{Applicability of fundamental freedoms to donations to charities}

It was evident that a donation (which lacks consideration) does not fall into the ambit of the freedom of establishment (governed by Arts. 43 to 48 of the EC Treaty).

However, the European Court of Justice decided that a donation (whether monetary or non-monetary) falls into the ambit of the free movement of capital (as to which see Art. 56 of the EC Treaty), read in connection with the nomenclature in Annex I to the (former) Council Directive 88/361/EEC of 24 June 1988. Indeed, according to Chapter XII of that Directive ("Personal Capital Movements") "gifts and endowments" as well as "inheritances and legacies" fall into the ambit of Art. 56 of the EC Treaty also. ${ }^{13}$ Although it may seem surprising that the 'market freedoms' of the EC Treaty are also applicable in such "altruistic" cases, the wording of the nomenclature is very clear. Consequently, the European Court of Justice had already decided that even inheritance falls into the scope of Art. 56 of the EC Treaty, read in connection with the nomenclature in Annex I on the (former) Council Directive 88/361/EEC, Chapter XII. ${ }^{14}$

\subsubsection{No justification}

The European Court of Justice again made it clear that restrictions of the fundamental freedoms cannot be justified in the field of the taxation of charity more easily than elsewhere. ${ }^{15}$ This result is consistent, if you take into account the fact that the strict focus on the divergence in residence made the Persche case similar, if not equivalent, to the Stauffer case, in which the European Court of Justice had already stated emphatically that treating a recipient charity differently based on the mere fact that it has its seat and actual place of management in a different EC member state means a discrimination which cannot be justified as a general rule.

In order to avoid tax abuses, a member state-however-is entitled to require documents from the donor who has to prove that the foreign charity meets all requirements of the national tax law. ${ }^{16}$

\subsubsection{Comparability - a question for the National Court}

The question of comparability (i.e., of whether a donation to a resident foundation in such a case be accepted as a tax-exempt donation under German law) could not be

\footnotetext{
${ }^{13}$ Case C-386/04, [2006] ECR I-8203, paragraph 23 et seq.

${ }^{14}$ Case C-364/01 Heirs of Barbier v Inspecteur van de Belastingdienst Particulieren/Ondernemingen buitenland te Heerle ECR [2003] I-15013; Case C-513/03 Van Hilten-van der Heijden ECR [2006] I-1957.

${ }^{15}$ Case C-386/04, [2006] ECR I-8203, paragraphs 38 et seq.

${ }^{16}$ Case C-386/04, [2006] ECR I-8203, paragraphs 51 et seq.
} 
decided by the European Court of Justice, since this is a question pertaining to German national tax law, which falls within the jurisdiction of the German (tax) courts. However, the European Court of Justice reiterated its statement that for this test, it is not sufficient that the Italian foundation has the status of a tax-exempt foundation according to Italian tax law. ${ }^{17}$

\section{A look forward: the comparability test as consequence of the general non-discrimination rule}

As the look back has shown meanwhile we can be sure that a non-discrimination rule exists because European law prohibits national tax law rules which discriminate foreign-based charities against residential charities, if the foreign-based charity is comparable to a residential charity. It is not surprising that the Commission has started to use infringement procedures in order to certify that the tax law of the member states respects the non-discrimination rule developed by the European Court of Justice.

However, the necessary comparability test do be performed by national taxation authorities and/or competent national courts can be quite complex and difficult.

\subsection{Previous research by comparative legal scholars}

Fortunately there has been some comparative legal research in the last decade in several member states. ${ }^{18}$ On that basis we are now able to state that there seem to be a number of similarities in structure, but also some differences in detail in the member state approaches. However, this research is still unfinished. Thus nobody can give a comparative analysis of all similarities and differences between the requirements for tax benefits in the 27 member states.

Unfortunately, some requirements are not explicitly stated in the written law, but have been developed or concretised by national taxation authorities and/or national courts. For example most member states lack a conclusive enumeration of what purposes are regarded as charitable or public benefit.

This legal uncertainty complicates the comparability test.

3.2 The challenge: what kind of "difference" makes a foreign-based charity incomparable?

As the experiences of numerous legal comparative studies show it can be difficult to decide, whether a 'difference' makes a foreign charity incomparable.

The 'difference' can be a pure terminological difference i.e., one which seems to be a difference on first sight, but is not a real difference, if the content of the legal

\footnotetext{
${ }^{17}$ Case C-386/04, [2006] ECR I-8203, paragraphs 43 et seq.

${ }^{18}$ See for example in Germany: ifo Institut für Wirtschaftsforschung an der Universität München [2]; Walz/von Auer/von Hippel [5].
} 
rule is analysed. If the 'difference' is a real difference, it can be a stricter rule or a less strict rule.

In order to decide whether the foreign-based charity meets the criteria of the national law (i.e., whether it is comparable to a residential charity) it must be recalled:

- A pure terminological difference does not make a foreign-based charity incomparable.

- The same is true, if the foreign law has stricter rules than the national law, because it is sufficient that the foreign-based charity meets the requirements of the national law.

- If the national law is stricter than the foreign law, additional tests will be necessary. In such a case, it will have to be tested whether the individual foreign-based charity has voluntarily (i.e., in its articles of association) decided to follow a stricter approach which may be sufficient for the standards of the national law. Another fundamental question is whether slight differences are tolerable or whether every slight difference will lead to the foreign-based charity being incomparable.

It should be noted that the foregoing approach to classification is a theoretical one, however. In practice it can be difficult to decide which category is applicable.

\subsection{An example: does the Italien "Stauffer" foundation meet the requirements of German tax law?}

In the Stauffer case (which has been dealt with in the text above) in the wake of the ruling of the European Court of Justice, the German Federal Tax Court (Bundesfinanzhof) still had to decide whether the Italian foundation met the requirements of German tax law. ${ }^{19}$ As it was uncertain whether the Italian foundation met several criteria which exist in German tax law, but not in Italian tax law, the Federal Tax Court referred the case back to the Local Tax Court (Finanzgericht) in order to clarify the facts.

\subsubsection{Introductory remarks}

A comparative legal scholar who has the task of comparing the German and the Italian requirements for tax benefits for charities will quickly realise that it is not easy to find the Italian law, as the Italian relevant legal rules are spread widely among diverse special codes and decrees. ${ }^{20}$ If you compare the rules you will find several negligible differences in terminology and the following four points, where German tax law has stricter rules than Italian tax law:

- Under German tax law the articles of association explicitly have to specify several requirements (see $\$ \$ 59,60$ Abgabenordnung-AO). These "formal requirements on the articles of association" ("Formelle Satzungsanforderungen") are stricter than the legal requirements under Italian tax law.

\footnotetext{
${ }^{19}$ See German Federal Tax Court (Bundesfinanzhof), decision of 20.12.2006, Case I R 94/02, published in Deutsches Steuerrecht (DStR) 2007, pp. 438 et seq.

${ }^{20}$ See further Runte/von Hippel [3], pp. 344 et seq.
} 
- German tax law requires that German charities state explicitly in their articles of association that in case of the liquidation of the charity the remaining assets have to be used for other charitable purposes ("Gebot der Vermögensbindung"). ${ }^{21}$ Under Italian tax law such a duty does not exist.

- In Germany there exists the "duty of timely disbursement" ("Gebot der zeitnahen Mittelverwendung”, see $\$ 55$ para. 1 No. 5 AO) requiring that generally $70 \%$ of the annual net income be distributed. ${ }^{22}$ In Italy a comparable such duty exists in Italy.

- Finally, German tax law requires a "rule of directness" ("Gebot der Unmittelbarkeit", see $\$ 57 \mathrm{AO}$ ), which means that a German charity usually has to promote its charitable purpose by itself (which involves the notion of an operative charity). There are however numerous exemptions from that rule, especially by a clarification in the articles of association of charity.

In its (second ${ }^{23}$ ) Stauffer decision, the German Federal Tax Court discusses all these differences.

\subsubsection{Formal requirements on the articles of association}

As regards the formal requirements of the articles of association, the Federal Tax Court held that the wording of the articles of association of the Italian "Stauffer" Foundation met the requirements of the German law in the individual case. According to the court "an interpretation of the articles of association of a charity should avoid an excessively narrow-minded finickiness" ("bei der Auslegung der Satzungen von Körperschaften, die Steuervergünstigungen wegen Verfolgung gemeinnütziger, mildtätiger oder kirchlicher Zwecke beanspruchen, [sei] eine allzu kleinliche ,Wortklauberei'[...] zu vermeiden"). ${ }^{24}$

\subsubsection{Explicit dedication to other charitable purposes in the case of dissolution and liquidation}

The articles of association of the Italian "Stauffer" Foundation lacked an explicit provision that in case of its dissolution and liquidation the remaining assets had to be used for other charitable purposes. The Federal Tax Court opined that the exemption rule of $\$ 62 \mathrm{AO}$ (which has since been abolished by the German legislator) could be applicable. That rule had an exemption for foundations (because it was believed that the additional supervision by the provincial state supervisory agencies would be sufficient). The Federal Tax Court thus opined that state supervision by the Italian foundation state supervisory agency could also be sufficient, if the rules of the Italian law on state supervision were "comparable in the main" ("in ihren wesentlichen

\footnotetext{
${ }^{21}$ See $\$ \$ 55$ paragraph 1 No. 4, 61 AO.

${ }^{22}$ But note that the German law also has several exemptions from that rule, if there is a specific justification, e.g., in order to finance a specific capital project (e.g., the construction or improvement of a building) in due time.

${ }^{23}$ The first Stauffer decision of the German Federal Tax Court (BFH) was the reference for a preliminary ruling by the ECJ.

${ }^{24}$ See BFH, DStR 2007, 438, 439 et seq.
} 
materiellen Belangen") to the German rules. ${ }^{25}$ This test of the comparability of the Italian and German State supervision on foundations should be carried out by the Local Tax Court as the competent court for investigations of the concrete facts. ${ }^{26}$

\subsubsection{Rule of timely disbursement}

The Federal Tax Court stated that it was "uncertain" ("ungewiss") whether the Italian "Stauffer" Foundation had met the requirements of the rule of timely disbursement and of the rule of directness. In order to answer this question, further investigation was necessary. The Federal Tax Court instructed the Local Tax Court to clarify this point also. $^{27}$

\subsection{Personal statement}

The argument of the German Federal Tax Court reveals that the test of comparability can be fairly complex and leave quite considerable room for interpretation because of legal uncertainty.

As regards the formal requirements on the articles of association the statement of the Federal Tax Court is convincing, because a "narrow-minded finickiness" does not make much sense, if a document has to be translated in another language and another legal terminology.

More problematic is the requirement of an explicit dedication of assets to other charitable purposes in the event of dissolution and liquidation. The interpretation of the former exemption of $\S 62 \mathrm{AO}$ by the Federal Tax Court seems to be comparatively generous. A stricter approach could have been used, but as $\$ 62$ AO has since been repealed, the topic does not need any further discussion.

In comparable cases in the future, it will be necessary to decide whether the lack of an explicit dedication of assets to other charitable purposes in the case of dissolution and liquidation by a non-German charity will lead to the result that the foreign charity does not meet the requirements of German tax law. That conclusion is reasonable, if the articles of association of the foreign foundation explicitly state that the assets of the foundation should be used for a non-charitable purpose in the case of dissolution and liquidation. But what if the foreign foundation law has the mandatory rule that the assets of a foundation must be used for another charitable purpose in the case of dissolution and liquidation? In such a case it would seem formalistic to require the explicit reiteration of a mandatory rule of a foreign law. In Germany such an explicit dedication is necessary, because German foundation law leaves the decision to the founder of what should happen to the assets of the foundation in case of dissolution and liquidation. In Italy, the laws draws a distinction. For some charities (e.g., organizzazioni non lucrative di utilità sociale (ONLUS) and Foundations of Banking Origin), a mandatory duty exists to dedicate the remaining assets to another charity in the case of dissolution and liquidation.

\footnotetext{
${ }^{25} \mathrm{BFH}$, DStR 2007, 438, 440.

${ }^{26} \mathrm{BFH}$, DStR 2007, 438, 440.

${ }^{27} \mathrm{BFH}$, DStR 2007, 438, 440.
} 
For the "Stauffer" Foundation that would mean that either the supervision by the Italian State of Italian foundations is "mainly comparable" to the German State supervision on German foundation or that the "Stauffer" Foundation is among the subcategories of Italian charities (e.g., ONLUS) for which a mandatory duty exists to use the remaining assets for other charitable purposes in the case of dissolution and liquidation.

The duty of timely disbursement is unknown in Italy. The approach of the Federal Fiscal Court is that it is necessary to investigate whether the Italian foundation has fulfilled a requirement, which is unknown under its domestic law, but necessary under German law.

However, the result of that test is not always clear. It should be noted that in case of a violation against the rule of timely disbursement the German taxation authorities can set a time limit in order to correct the violation. This procedure seems to be the usual approach taken in the case of violations against the rule of timely disbursement. ${ }^{28}$ So it is open to discussion whether the German taxation authorities can, should or even must also give a foreign charity the opportunity to correct the violation against a German tax law rule which may seem unknown to them before.

It can be complex to decide even under German law, whether one of the numerous exemptions to the German "rule of directness" is applicable. In the other member states, where this German rule seems to be widely unknown, it seems not always to be easy to investigate whether one of these exemptions is applicable.

\section{Ways to facilitate the situation}

\subsection{Introduction of model statutes}

The example of the "Stauffer" Foundation may illustrate that it is theoretically possible that an Italian foundation - and any other charity in a member state-meet the requirements of German tax law. It is just necessary for it to implement the requirements of German tax law in its articles of association and to comply with its articles of associations.

However, in practice, considerable barriers to such an approach will not infrequently be encountered:

- Often there will be a lack of knowledge of the requirements of foreign tax law, especially because it is not easy to understand and to interpret the written provisions of the foreign tax law.

- Up to now, no "model statutes" exist which could help to overcome the lack of knowledge. It should be borne in mind that what is being discussed is a matter which is far from trivial. The complexity of information required by 27 member states does not suggest that facilitating the availability of the information needed could be organised easily. Such an effort to inform would require at least a highly competent unit of monitoring experts which would have to process the information with the lowest possible risk of errors and incorrectness. The results of any

\footnotetext{
${ }^{28}$ See Eversberg [1], p. 64.
} 
such information approach would either have to be in the form of a fairly comprehensive online information portal or a handbook-style publication, but certainly not a collection of information brochures. The very fact that 27 member states are involved creates a substantial level of complexity-because of the number of possible combinations - which can not be reduced.

- Existing charities may find it difficult to amend their articles of association (e.g., some national legislative acts concerning foundations are comparatively restrictive as regards amendments of the articles of association, especially in the case of an amendment of the foundation's purpose).

\subsection{Establishment of a network of charities}

The traditional solution used to overcome current barriers to cross-border activities is the establishment and maintenance of a network of charities. In every member state where tax benefits are necessary, a charity is established which has to be coordinated with the other charities in the other member states.

Examples of such networks can be found in practice, but it should be noted that the establishment and maintenance of such a network is comparatively expensive.

\subsection{Legislation by the member states}

Another way to facilitate the situation would be legislation by the member states on a national or European level.

\subsubsection{National level}

On the national level the member states could facilitate the situation by treaties by clearly-arranged requirements for foreign charities helping them to cope with the requirements of national law. ${ }^{29}$

\subsubsection{Harmonisation of the requirements for tax benefits}

A (partial) harmonisation of the requirements for tax benefits would facilitate the situation and reduce the costs for cross-border activities in a very substantial way, because charities would find the same legal environment in all member states. It seems completely unrealistic to expect that such model could be implemented

\footnotetext{
${ }^{29}$ Of course, a member state, can also try to go the opposite way: to make the national law more complex in order to complicate the situation for foreign charities to fulfill its national requirements. The recently new implemented $\$ 51$ para. $2 \mathrm{AO}$ of the German tax law may be regarded as such an example. According to that provision the promotion of charitable purposes abroad should promote German citizens or inhabitans or "the activities of the foreign charity should, apart from the promotion of its charitable purpose, also be suited to promote the reputation of the Federal Republic of Germany" ("dass [...] die Tätigkeit der Körperschaft neben der Verwirklichung von steuerbegünstigten Zwecken auch zum Ansehen der Bundesrepublik Deutschland im Ausland beitragen kann"). This rule creates legal uncertainty, but-if you read it-you can hardly imagine a case where the reputation of Germany cannot be promoted, unless the activities of the foreign charity are against the German laws or the German ordre public (e.g., promotion of surrogate motherhood, promotion of rasistic sport clubs). Also under the former law it was undisputed, that tax benefits are not possible in such cases, however. That it is hard to find any case where the new $\$ 51$ para $2 \mathrm{AO}$ will become relevant in practice.
} 


\subsubsection{Bilateral and multilateral level}

Under a taxation law treaty each member state could mutually accord tax-exempt status to foreign charities, with the consequence that such foreign charities would receive the same tax benefits as a national tax-exempt charities. Thus, in theory, it is possible to overcome national legal barriers by the use of multilateral or bilateral treaties. However, there are still almost no multilateral or bilateral treaties between the member states in the field of charities: the Hague Convention on the Law Applicable to Trusts and on their Recognition from 1985 was only ratified by a few member states (viz., Italy, Luxembourg, Malta, the Netherlands and the United Kingdom). Tax treaties are even more of a rarity. One reason for this lack of treaties may be that it is not always easy to equate a foreign legal form with a national one, e.g., where a public benefit purpose is a requirement in national civil law and/or national tax law, this concept could have another meaning in other member states. Another factor is that some member states do not regard a foreign foundation as a resident of the other contracting state for the purposes of an income tax treaty where the foundation has no liability or only a partial liability to income tax in that other state. In view of these experiences, it seems unrealistic to expect the member states to ratify unilateral or bilateral treaties in the course of the next few years.

\subsubsection{Establishment of a European Foundation with tax-exempt status}

Finally, there could be an implementation of a European Foundation with tax-exempt status. Such a European Foundation would be an additional and optional instrument like the European Economic Interest Grouping (EEIG), the European Company (Societas Europaea, SE), the European Cooperative Society (Societas Cooperativa Europaea, SCE), and most recently and in particular the proposed European Private Company (Societas Privatae Europaea, SPE). The European Commission has just published a feasibility study on a European Foundation Statute which discusses the possibilities of such a new European legal form. ${ }^{30}$

The legal basis for a European Foundation Statute would be Art. 308 of the EC Treaty-combined with the fundamental freedoms (i.e., freedom of establishment, free movement of capital ) which seem to be applicable to most cross-border activities of foundations. Existing national foundations would be entitled to transform into a European Foundation, if such a transformation was in line with the will of the founder. The member states could provide for specific procedures allowing a transformation under the condition that the foundation's statutes can remain similar after the transformation.

If such a European Foundation were to have tax-exempt status in all member states the adoption of tax law rules would additionally be necessary. As regards the scope of such tax benefits, there are various options. It is arguable that instead of harmonisation, however, only a non-discriminatory solution is both realistic and reasonable. Thus, a European Foundation would receive the same tax benefit as a tax-exempt foundation in the same member state.

${ }^{30}$ See http://ec.europa.eu/internal_market/company/eufoundation/index_en.htm. 
As regards the implementation of the additional tax law rules, there could be an implementation by the European Foundation Statute itself, by an additional treaty, or (automatically) by adopting the lowest common denominator of the national tax laws of the member states. While the two first options do not seem to be very realistic, the third option may be worth considering: According to the new adjudication by the European Court of Justice in Stauffer, it is unlawful to deny tax-exempt status to a foreign foundation if this foundation meets all other requirements of a national tax-exempt foundation of the state in question. Thus, theoretically the European Foundation would be automatically tax-exempt in the member states, if the European Foundation Statute were to combine all requirements of the tax law of the member states (the de facto lowest common denominator). The requirements of tax law could be mandatory for all European Foundations or be part of a supplementary 'model statute', leaving it open to the founder whether she/he wants the additional advantage of the status of a tax-exempt foundation in all member states. At first sight, such a tax-exempt European Foundation may seem unrealistic, because it would be over-regulated and too 'bureaucratic'. However, according to the results of comparative legal studies of tax law concerning charitable foundations, the similarities in tax law seem to be much greater than in the law of charitable foundations. Thus it is not unimaginable that such a European Foundation could be a viable proposition and that the cost of more bureaucracy may make it worth considering tax-exemption in all member states.

\section{Conclusions}

1. All member states have tax privileges for charities (public benefit organisations) which are generally also applicable if a charity resident in the jurisdiction performs cross-border activities. However under their current tax law almost all member states grant tax benefits only to resident charities, not to foreign-based charities.

2. Meanwhile the European Court of Justice has made clear in Stauffer and Persche that such discrimination infringes the EC Treaty. The European Court of Justice has established a non-discrimination rule in tax law which prohibits a foreignbased charity being discriminated against, if this foreign-based charity meet the requirements of the national tax law for a residential charity.

3. A consequence of this non-discrimination rule is the need for challenging "comparability tests" as to whether a foreign-based charity meets the requirements for the tax benefits in the State of source.

4. It would be helpful to find ways to facilitate the "comparability test". Otherwise it seems probable that charities will not be able to take advantage of the jurisprudence of the European Court of Justice. In some cases model statutes can be a helpful tool. A more general approach would be intervention by the national or European legislator (e.g., by establishing a European Foundation as a new optional legal form apart from the national forms of charitable foundation already existing in member states). 
Open Access This article is distributed under the terms of the Creative Commons Attribution Noncommercial License which permits any noncommercial use, distribution, and reproduction in any medium, provided the original author(s) and source are credited.

\section{References}

1. Eversberg, H.: In: Kötz, H., Rawert, P., Schmidt, K., Waltz, R. (eds.) Non Profit Law Yearbook 2003, pp. 59. Hamburg (2003)

2. Ifo Institut für Wirtschaftsforschung an der Universität München: Die Besteuerung gemeinnütziger Organisationen im internationalen Vergleich. München (2005)

3. Runte, J., von Hippel, T.: Gemeinnützigkeits- und Spendenrecht in Italien. In: Walz, W.R., von Auer, L., von Hippel, T. (eds.) Spenden- und Gemeinnützigkeitsrecht in Europa, pp. 341. Tübingen (2007)

4. von Hippel, T., Walz, W.R.: General report. In: Walz, W.R., von Auer, L., von Hippel, T. (eds.) Spendenund Gemeinnützigkeitsrecht in Europa, pp. 89. Tübingen (2007)

5. Walz, W.R., von Auer, L., von Hippel, T. (eds.): Spenden- und Gemeinnützigkeitsrecht in Europa. Tübingen (2007) 